\title{
Invited Commentary: A Practitioner's Journey into Developmental Research
}

\author{
Donald T. Floyd
}

Published online: 22 May 2010

(C) Springer Science+Business Media, LLC 2010

My journey with Richard Lerner and something called Positive Youth Development (PYD) started two decades ago. I had just spent 17 years helping lead a different youth organization, one that did not know youth development theory but just "knew how to work with kids." Even today, most youth workers in the 30,000 youth organizations in America would say the same thing.

My first exposure to the idea that youth are assets and not problems to be fixed was in the auditorium of the National 4-H Youth Conference Center in Chevy Chase, MD in May, 1991. An amazing woman named Karen Pittman was speaking to a large group of 4-H Agents/ Educators presenting her theory about a fledgling but growing field of theory and practice called Positive Youth Development. I learned there were 5 C's-Competence, Confidence, Connection, Character and Caring-and the theory was that if youth could achieve these characteristics, then they would have a positive trajectory in life. I also learned that a fellow named Rick Little had established these constructs based on his learning as a social innovator. Rick was forming the International Youth Foundation about that time and would later go onto found ImagineNations, Silatech, and ImagineAfrica and become my close friend and colleague.

I met Rich in the same auditorium about that time, as he was articulating his view of PYD, building off of the $5 \mathrm{Cs}$ model and the strength-based, asset model of young people that he and others were creating (e.g., see Benson 2008; Damon 2008; Eccles and Gootman 2002; Larson 2000; Lerner 2007, for discussions). However, the model he

D. T. Floyd ( $\square)$

National 4-H Council, 7100 Connecticut Avenue,

Chevy Chase, MD 20815, USA

e-mail: dfloyd@fourhcouncil.edu presented involved mostly untested hypotheses. We, in youth development practice, were not giving him and his colleagues much help in obtaining information to help test these ideas.

Let's face it, as recently as 10-15 years ago, if any of us in youth development practice were actually doing research it was pre/post-testing or "research" to prove our programs worked. Very few of us were investing in high quality research that could show if the practice models really worked. In fact, in the late 1990s, Roth, Brooks-Gunn and their colleagues published a meta-analysis that stunned me (Roth et al. 1997, 1998). Of the then 17,500 youth organizations in America, only 11 had actual, solid evaluation data that could speak to the effectiveness of their programs. In other publications, Roth and Brooks-Gunn (2003a, b, see too Lerner 2004) also articulated the "Big Three" features of programs that appeared to foster PYD: (1) long-term relationships with a caring adult; (2) life-skill learning; and (3) youth as leaders. These were common threads among those youth organizations that had the effective evaluative data and were effective programs.

It was also during this still early period in the development of the research base for the PYD model that Judy Vredenbergh, of Big Brothers Big Sisters of America (BBBSA), commissioned the Private/Public Ventures (PPV) organization to rigorously evaluate the effects that the BBBSA model had on the youth they served. The results of this evaluation were spectacular and they helped bring BBBSA onto the national stage.

Therefore, it appeared that it was possible that those of us in the practice field could actually shift from relying on decades of anecdote-laden, powerful, individual youth testimony presented at fund raisers to relying on real research and evaluation about our programs and, if so, to let the chips fall where they may. This was a key question 
but many practitioners did not need to worry about entertaining it! Very few funders would pay for evaluation and almost no one was paying for real research, the kind where the researcher was actually allowed to find out what is true and not be asked to tailor a study to reach a designated conclusion. Such research was a risky proposition, but a few of us believed it had to become a reality.

Two things happened at the end of the 1990s and the beginning of the new decade and century, however, that helped such research come to fruition. When National 4-H Council was about to begin work with Philip Morris USA Youth Smoking Prevention's (YSP) team to design a highly effective youth smoking prevention program (labeled HealthRocks!), the DARE program evaluations were hitting the headlines. The news was they were not effective; it was clear to me that we could never let that happen to 4-H. We could not spend hundreds of thousands, if not millions, of dollars to design a program without real, rigorous research to say what worked and what did not. In all my years of working with the YSP teams and in many meetings with CEO Mike Symancyk at PMUSA they only ever said two things said to us: "Do this program well" and "Research its effectiveness so everyone will know whether it works or not."

We decided to launch an aggressive research program to find out if HealthRocks! actually worked. After considering several research labs we selected the one led by Richard Lerner, frankly because he was a true researcher with uncompromising integrity and credentials. ${ }^{1}$ Therefore, I posed the question to him: Will you design a research program, get an advisory team, and tell us if HealthRocks! is effective or not? Rich went on to do just that, and a great advisory board met at National 4-H Council (interestingly, on September 10,2001) to develop a plan to guide the work. Phillip Morris agreed to fund this independent research project through National 4-H Council. Rich assembled an amazing team that designed the study. Based on the advice of the advisory board, the Lerner group started with 10 year olds and planned to longitudinally study these young people for eight years...through the course of adolescence. This plan consisted of what I term a WOW, especially because Rich said that to do the study correctly we needed to find out if the PYD model was valid. He explained that our approach to youth smoking prevention was in effect based on a PYD model, an idea that Philip Morris and some of my colleagues did not initially recognize. The framing of the study in this way was

\footnotetext{
${ }^{1}$ In addition, he had the personality to deal with the possibility of finding and reporting results that could have reflected poorly on our programs. He was "a tough kid from Brooklyn" with whom you could not "mess," that is, I knew that potential pressure from funders or program personnel would not deter him from reporting what he found.
}

an exciting moment because we could finally know if the 5 Cs were in fact a reality.

As the Lerner team conducted this longitudinal research, they used impeccable scientific methods and put all the papers they derived from the research through a rigorous peer review process in order to publish their results in the field's best journals. In addition, they were able to attract world-class Ph.D. students and post-doctoral fellows to assist in the research. Tufts University became quite proud of Lerner's lab, the Institute for Applied Research in Youth Development (IARYD), and the ground-breaking research it was accomplishing. We are all grateful to the Bergstrom Family for endowing Dr. Lerner's chair at Tufts. I got to know Dr. Joan Bergstrom, who chaired the IARYD advisory committee, and her brilliant, compassionate leadership lives on to this day. At this writing, we just learned of her death and it is fitting that this journal special issue comes at a time of expression of joy and gratitude for her life, accomplishments, and friendship.

Today we know not only that the $5 \mathrm{Cs}$ do in fact exist and that they help define a thriving young person, but we can actually measure them in children and adolescents and create a PYD score. The connection then of lower PYD scores to depression, smoking, drug use, and other risk behaviors and, in turn, the connection between higher PYD scores to contributions to self, family, and society should make this score a vital component of the design and of the measurements used in any youth program.

What we have learned from this research infuses federal agency policy, guides the decisions of funders, aids in the design of youth organization practice, and helps all of us realize, adults and youth, that young people are amazing assets in their communities. The massive data set that has been created by Richard and Jacqueline Lerner's team at IARYD over the last decade will become one of the legendary research data sets, one that will be used by many researchers for decades to come. What the Framingham study did for heart treatment, their PYD research will do for all youth organizations. In fact, today, many Ph.D. students that came out of this lab and used the PYD study data for their research are in significant leadership roles in many youth-serving organizations.

For the field, the research provides a proven model that can change policy and practice, and the continuing publication of the findings emanating from this project-such as those presented in this special issue-will likely become increasingly more widely used. For those of us in 4-H, this study has been a collective affirmation of what we knew in our hearts: We had a great program. But, today, scientific research from this project tells us that we not only have a great program, we have one of the world's best ideas, one that helps youth reach their full potential. To the many who are involved with this research you have our gratitude for 
your courage, your independence, and your scholarship! Thank you.

\section{References}

Benson, P. L. (2008). Sparks: How parents can help ignite the hidden strengths of teenagers. San Francisco: Jossey-Bass.

Damon, W. (2008). The path to purpose: How young people find their calling in life. New York: Free Press.

Eccles, J., \& Gootman, J. A. (Eds.). (2002). Community programs to promote youth development. Washington, DC: National Academies Press.

Larson, R. W. (2000). Toward a psychology of positive youth development. American Psychologist, 55(1), 170-183.

Lerner, R. M. (2004). Liberty: Thriving and civic engagement among American youth. Thousand Oaks, CA: Sage.

Lerner, R. M. (2007). The good teen: Rescuing adolescence from the myths of the storm and stress years. New York: Crown Publications.

Roth, J. L., \& Brooks-Gunn, J. (2003a). What is a youth development program? Identification and defining principles. In F. Jacobs, D. Wertlieb, \& R. M. Lerner (Eds.), Enhancing the life chances of youth and families: Public service systems and public policy perspectives: Vol. 2 Handbook of applied developmental science: Promoting positive child, adolescent, and family development through research, policies, and programs (pp. 197-223). Thousand Oaks, CA: Sage.

Roth, J. L., \& Brooks-Gunn, J. (2003b). What exactly is a youth development program? Answers from research and practice. Applied Developmental Science, 7, 94-111.
Roth, J., Brooks-Gunn, J., Galen, B., Murray, L., Silverman, P., Liu, H., et al. (1997). Promoting healthy adolescence: Youth development frameworks and programs. New York: Teachers College, Columbia University.

Roth, J., Brooks-Gunn, J., Murray, L., \& Foster, W. (1998). Promoting healthy adolescents: Synthesis of youth development program evaluations. Journal of Research on Adolescence, 8 , 423-459.

\section{Author Biography}

Donald T. Floyd, Jr. is president and CEO of National 4-H Council, the private sector, non-profit partner of America's largest youth organization operating in every county. $4-\mathrm{H}$ is a community of more than 6.5 million young people across America learning leadership, citizenship and life skills. 4-H also has partners in over 80 countries. Mr. Floyd has been associated with innovative leadership of youthserving, non-profit organizations for more than 35 years. For 17 years, he held local and national level positions, including National Executive Vice President of Junior Achievement. With Junior Achievement, he led expansion of the international program and its first venture into classroom-based programming, which today is JA's largest program. Don recently completed his term as Chair of the National Collaboration for Youth (a coalition of the top 56 youth organizations) and is currently a Trustee with the America's Promise Alliance. He is former Chair of the International Leaders Committee of the Institute for Applied Research in Youth Development, Tufts University. He was one of six inaugural recipients of the International Fellows in Applied Developmental Science. 